\title{
MARKET ORIENTATION IN SOCIAL HOUSING MANAGEMENT
}

Social housing has traditionally been provided through bureaucratic mechanisms. The development and management of social housing have been driven to a large extent by government finance and subsidisation and the legislation associated with it. As a consequence, social landlords have operated mainly in a task-oriented way, as an annexe to the government.

In the last 10 to 20 years, many governments in Europe transformed their housing systems to include or to reinforce market principles. Consequently, social landlords have been stimulated to increase their market orientation. In many countries direct financial support from the government has been reduced, so that social landlords have to finance more of their activities from their own or from private resources. In some countries legislation has been reduced as well, placing more responsibilities at the level of the individual landlords and leaving them with the challenge to make strategic decisions on their own. And, in some countries legislation is even explicitly stimulating that landlords should take on a more business-like approach by requiring them to develop business plans and asset management schemes.

One of the main arguments that is put forward for a stronger emphasis on market principles is that this could lead to a more efficient social housing system (not to mention a reduction of government expenditure). However, these reforms could also lead to a less effective social housing system, resulting for example in insufficient development of affordable dwellings, high rent-increases and the allocation of fewer dwellings to 'risky' households. So, increased market orientation in social housing management could have its benefits, but there are pitfalls as well. One could even ask if market orientation should be reinforced in social housing management at all, since social housing was invented precisely to solve or prevent the undesired effects of a free market.

We argue that market orientation should be reinforced in the social rented sector. But, before we put forward our argument, it is useful to discuss the concept of market orientation in some more detail. In our view, market orientation within social housing management stands for following a (pro)active approach in attuning the housing stock and services to market demand and social housing needs. Furthermore, market orientation stands for seizing opportunities to make a profit (or at least to optimise financial return) where that is possible without endangering the fulfilment of the social objectives. Of course, market orientation in social housing management must not be mistaken with market conformity in which maximising profits is the lead motive. Market orientation can be set against the traditional, task-oriented approach that many social landlords have followed - and still follow - in which they focus solely on the production and management of cheap and decent dwellings, with only a limited differentiation in rents, quality, tenure and target groups, and often without attuning these factors to each other.

A more market-based system could lead to a more effective, efficient and, in some respect, fairer social housing system. If landlords become more responsive to market demand and market dynamics they can become more effective in meeting their tenants' 
preferences and financial possibilities. Within current housing systems, there are numerous examples in which tenants pay the same for dwellings of a different quality, which can be seen as unfair. Moreover, some low-rent dwellings are allocated to more well-to-do households. Thus, these tenants pay less than they can afford and they do not really need the (implicit) housing subsidy. In a market-oriented system, one may expect a better relation between price and quality and inefficiencies in the allocation of financial means are less likely to occur. Furthermore, social landlords are stimulated to seize opportunities to raise (additional) money that can be used for social objectives, such as new housing developments and regeneration of urban areas. In this way, they could improve their overall effectiveness as social housing providers.

Thus, increased market orientation can help to overcome the inefficiencies that are often associated with social housing, but it can have (other) social benefits as well. If social landlords can be active in other segments of the housing market (e.g. by also providing owner-occupied dwellings and more expensive rental dwellings), they would be able to loose or to avoid the image of being solely providers of housing for the poor. Consequently, their tenants will be in less danger of being stigmatised. Furthermore, social landlords will be able to contribute to differentiated neighbourhoods and thus help to combat social and spatial segregation.

Notwithstanding the advantages of more market orientation, one must be aware of the pitfalls as well. In our opinion, the most important pitfall is that the stimulation of market-orientation among social landlords could eventually lead them to adopt a marketconform approach, in the sense that social objectives and considerations will gradually disappear and that profit-making will become the lead motive. Then, social landlords will lose their position as effective contributors to the fulfilment of social housing needs. In recent discussions in, for example the Netherlands and England this is recognised as a serious threat. Therefore, the stimulation of market-orientation in the social rented sector must go hand-in-hand with a system in which social landlords are accountable for their performance as providers of decent, affordable social housing. Under such conditions, market orientation in the social rented sector could contribute to a more efficient use of the financial means, to achieve tenants' satisfaction (by increasing client-oriented behaviour) and the prevention of stigmatisation and segregation.

As part of the stimulation of market orientation in social housing management, it is interesting for social landlords to see if they can learn from management approaches that have been developed in the private sector. Social landlords can - and have indeed begun to do so in some cases - implement methods and approaches such as benchmarking, portfolio analysis, balanced score cards, swot analysis and strategic business planning. In our paper in this issue we show various examples of how this can be done. But to avoid the pitfall we just mentioned, the methods from the private sector need to be adapted to fit the context of social housing. While in the methods from the private sector the emphasis naturally lies on financial performance, social landlords must find ways to incorporate social returns in their decisions as well (see, for example, the remarks that we have made in our paper in this issue on the decision tree that is used by the Dutch housing association Delftwonen). 
Our recent study ${ }^{1}$ into the practice of eight European countries and Australia shows that the development of a more strategic asset management in the social rented sector is at a very early stage, although there are certainly front runners among social landlords. It is exactly in this early stage of development that landlords can benefit the most from the exchange of experiences. ${ }^{2}$ So we warmly invite academics and professionals from the social and private housing sector to submit their views.

Vincent Gruis and Nico Nieboer

Delft University of Technology

\footnotetext{
${ }^{1}$ Gruis, V. and Nieboer, N. (eds., 2004, forthcoming) Asset management in the social rented sector; policy and practice in Europe and Australia.

${ }^{2}$ A workshop will be held on housing asset management at the forthcoming conference of the European Network for Housing Research in Cambridge (2-6 July); see www.enhr2004.org for details.
} 